\title{
Gdy mówi do nas język. Krytyczne spojrzenie na współczesne aplikacje hipotezy Sapira-Whorfa w feministycznych teoriach językoznawczych
}

\section{When language speaks. A critical analysis of contemporary applications of Sapir-Whorf hypothesis in feminist linguistic theories.}

\author{
Michal Jahns \\ DePartment of Media, Culture and LANGUAGE \\ ROEHAMPTON UNIVERSITY; ROEHAMPTON LANE \\ LONDON SW15 5SL. (ROEHAMPTON UNIVERISTY, LONDYN)
}

\begin{abstract}
In this paper I discuss a common argument put forward by the feminist movement and present in academic publications in the field of gender and language studies. Based on the assumption that language is not a transparent means of communication, the argument states that a patriarchal worldview is embedded in linguistic structure of Polish and other languages. This leads some feminist activists to advocating language change that would alter certain elements of linguistic structure in an attempt to eradicate the perceived bias. I argue that the feminist argument is based on a debatable interpretation of the Sapir-Whorf hypothesis that does not take into consideration recent developments in the field, notably the theory of language ideologies. I conclude that for a scientific investigation of values allegedly carried by language, it is necessary to go beyond the study of linguistic structure alone and incorporate methods of other social sciences that will allow us to grasp the social context from which language cannot be ultimately separated.
\end{abstract}


Michal Jahns: Gdy mówi do nas język. Krytyczne spojrzenie...

\section{Wstęp}

Podczas wykładu poświęconego hipotezie Sapira-Whorfa pewien profesor, chcąc wykazać absurd radykalnych interpretacji prezentowanej teorii, zapytał swoich studentów, czy według nich fakt, że w Brazylii zjazd z autostrady określa się wyrazem „entrada” (czyli „wejście”), a w języku angielskim wyrazem „exit” (czyli „wyjście”) sprawia, że użytkownicy tych języków mają diametralnie różne obrazy mentalne systemów drogowych krajów, w których żyją. Jego brazylijscy studenci zaskoczyli go jednak, na zawołanie prezentując kilka teorii tłumaczących pochodzenie tej różnicy i wyrażających różne sposoby myślenia o transporcie drogowym. Gdyby ów profesor, uznający przytoczone przez studentów wyjaśnienia za całkowicie nienaukowy ciąg stereotypów czy wręcz absurdalnych nadinterpretacji, nie przerwał dyskusji, można by się spodziewać, że rozwinęłaby się ona $\mathrm{w}$ kłótnię o to, która z wymyślonych teorii jest „prawdziwa” (Kay 1996: 97).

Biorąc udział $\mathrm{w}$ wielu dyskusjach dotyczących feministycznych teorii językoznawczych i postulowanych przez feminizm zmian w języku oraz śledząc tą debatę w środkach masowego przekazu, wielokrotnie odnosiłem wrażenie, że ich krytycy i krytyczki (czy to lingwiści, czy osoby nie zajmujące się zawodowo językiem1[1]) uważają niektóre teorie feministyczne za równie absurdalne, co spekulacje na temat wpływu etymologii wyrazu określającego zjazd $\mathrm{z}$ autostrady na obrazy mentalne systemów drogowych. Feministki zaś odrzucają argumenty krytyków, raczej jako atak z poziomu konserwatywnych wartości niż przejawy krytyki feministycznych metod badawczych. Prowadzi to do blokowania debaty w martwym punkcie, który rzadko udaje się przekroczyć. Intrygujące są tu jednak dwie rzeczy. Po pierwsze - to, jak latwo, z jaką energią i przekonaniem sympatycy ruchu feministycznego wyciągają ogólne wnioski na temat relacji między pojedynczymi formami językowymi a społecznokulturową pozycją kobiet $\mathrm{w}$ polskim społeczeństwie. Po drugie zastanawiające jest nie przywiązywanie większej wagi do typu działalności ludzkiej ze strony zawodowych badaczy języka. Mamy zatem do czynienia ze zjawiskiem powszechnym i potencjalnie znaczącym (wszak mającym związek ze stereotypami płciowymi i normami współczesnej polszczyzny), któremu językoznawcy poświęcają stosunkowo mało uwagi.

Celem tego artykułu jest analiza części założeń feministycznej krytyki języka, które, zdaniem autora, wywodzą się z leżącej u podstaw argumentu feministycznego problematycznej interpretacji hipotezy Sapira-Whorfa. Współczesne postępy $\mathrm{w}$ badaniach ideologii językowych $\mathrm{w}$ znaczącym stopniu rozwinęły nasze rozumienie procesów, których hipoteza dotyczy. Autor tego artykułu jest przekonany, że wzięcie ich pod uwagę otworzy nowe pole dociekań teoretycznych i badań, które umożliwią lepsze zrozumienie zależności między językiem a kulturą. $\mathrm{W}$ dalszej perspektywie dadzą uczestnikom debaty nad wprowadzeniem feministycznych zmian $\mathrm{w}$

1[1] Np. 4827 członków grupy „Feminizacja języka polskiego boli mnie w uszy” na portalu społecznościowym Facebook. 
języku konkretne argumenty, dzięki którym możliwa będzie bardziej merytoryczna dyskusja nad pożądanym kształtem polszczyzny.

Artykuł ten czerpie w dużej mierze z przemyśleń zawartych w pracy magisterskiej, napisanej przeze mnie pod opieką naukową Prof. Jerzego Pogonowskiego, któremu chciałbym w tym miejscu serdecznie podziękować za otwartość, z jaką podszedł do mojego projektu, krytyczne spojrzenie oraz za wsparcie, na które zawsze mogłem liczyć.

\section{Hipoteza Sapira-Whorfa i jej krytyka}

W najogólniejszym ujęciu hipoteza będąca tematem niniejszej pracy głosi, że kultura za pośrednictwem języka wpływa na to, jak myślimy (Gumperz i Levison 1996: 1). Od czasu kiedy Sapir i Whorf napisali prace (Sapir 1921, 1929, Whorf 1956), na podstawie których sformułowano hipotezę upamiętnioną ich nazwiskami (znaną także jako teoria relatywizmu językowego), jej losy toczyły się niezwykle burzliwie. Odważne wnioski wysunięte przez wczesnych badaczy, niezbyt precyzyjny sposób sformułowania, pozwalający przywoływać ją w istotnie różnych sytuacjach, oraz zgodność z potoczną wiedzą użytkowników języka doprowadziły do jej niezwykle szybkiej popularyzacji. Dużej liczbie prowadzonych $\mathrm{w}$ tej dziedzinie badań towarzyszyło powstanie obiegowych, popularnonaukowych „faktów” ufundowanych na wątpliwych podstawach empirycznych - przykładem niech będzie niesławne „eskimoskie 100 słów na śnieg" $2[2]$.

W lingwistyce popularność hipotezy Sapira-Whorfa była jednak krótkotrwała. Teoria gramatyki generatywno-transformacyjnej Noama Chomsky'ego, która stała się dominującym paradygmatem językoznawstwa lat sześćdziesiątych i siedemdziesiątych, skupiała się na cechach uniwersalnych, łączących wszystkie języki, nie zaś na różnicach między nimi (które leżały w centrum zainteresowania antropologicznie zorientowanej lingwistyki czasów Sapira i Whorfa). Ponadto, rozwój metod badawczych oraz dostępność coraz większej ilości materiału empirycznego z wielu języków nieindoeuropejskich pozwoliły dostrzec uproszczenia i pochopne generalizacje wczesnych badaczy relatywizmu językowego. Aneta Pavlenko (2005), podsumowując ten okres w dziejach głównych nurtów językoznawstwa, pisze za Lakoffem, że hipoteza Sapira-Whorfa stała się bête noir lingwistyki, utożsamiana była z nieodpowiedzialnym prowadzeniem badań, mętnym myśleniem i brakiem rygoru (Pavlenko 2005: 434). Aż do połowy lat osiemdziesiątych bardzo niewielu badaczy zajmowało się zatem relatywizmem językowym (godnym uwagi wyjątkiem są tu prace Della Hymesa).

2[2] Przypadek „100 słów na śnieg” jest o tyle ciekawy, że obecnie stał się jednym z popularniejszych zdemaskowanych mitów. Rozpowszechnienie w Internecie stron typu mythbusers.com oraz popularne książi Stevena Pinkera sprawily, że już pierwsze hasła z wyszukiwarki Google, w tym Wikipedia, informują nas o nieprawdziwości tego „popularnego faktu”. Nie zmienia to w żaden sposób tego, że wiele innych, podobnie zbudowanych „faktów” na temat różnych kultur i ich języków uchodzi za zdroworozsądkowe. „100 stów na śnieg” jest teraz wyjątkiem potwierdzającym regulę. 
Sytuacja zmieniła się dopiero z pojawieniem się badań Georga Lakoffa (1987), Johna Lucy'ego (1992, 1996), Dana Slobina (1996) i Stephena Levinsona (2003), których podejście Pavlenko określa zbiorczo jako neoWhorfiańskie, podkreślając jednocześnie istnienie różnic $\mathrm{w}$ pojmowaniu relatywizmu językowego przez poszczególnych badaczy. Ich wspólną zasługą było użycie konkretnych, zniuansowanych konceptualizacji dwóch stron zależności, o których mówi hipoteza: języka i myśli. Nie pisali już zatem o wpływie języka $\mathrm{w}$ ogóle na myślenie $\mathrm{w}$ ogóle, lecz tworzyli ograniczone modele teoretyczne wyodrębniające elementy języka, które mogły potencjalnie wpływać na niektóre procesy myślowe. Miało to zasadnicze znaczenie, ponieważ tak wyodrębnione zależności, w przeciwieństwie do szerokich generalizacji wczesnych badaczy relatywizmu, dało się testować empirycznie. Zdano sobie na przykład sprawę z różnicy pomiędzy badaniem myśli jako stanów, czyli idei, jakie użytkownicy mają na temat świata, oraz myślenia jako procesu, w którym przedmiotem badania są skupienie uwagi, pamięć czy wnioskowanie (Pavlenko 2005: 435). Zwrócono także uwagę na metodologiczny problem występujący we wszelkich badaniach stanów wewnętrznych ludzi. Ponieważ badacz nie ma do nich bezpośredniego dostępu, koniecznym staje się wnioskowanie na podstawie innych przesłanek. W przypadku badań relatywizmu językowego powstaje ryzyko badania niczego więcej jak tylko wpływu „języka na język”. Chcąc tego uniknąć, Lucy (1996) zaleca, aby - kiedy tylko jest to możliwe - uwzględniać także zachowania niewerbalne. Przykłady zachowań niewerbalnych wykorzystywanych $\mathrm{w}$ badaniach to: klasyfikowanie, dzielenie, łączenie $\mathrm{w}$ pary, testowanie pamięci i zadania wykorzystujące odgrywanie ról. Aspekt werbalny bada się najczęściej przez skojarzenia, inferencje, opis obrazków oraz przez wywiady, opowiadanie historii i inne zadania konwersacyjne (Pavlenko 2005: 435).

Z punktu widzenia krytyki feministycznej teorii języka, którą przedstawię $\mathrm{w}$ tym artykule, najistotniejszym wkładem badaczy relatywizmu językowego od drugiej połowy lat osiemdziesiątych było zwrócenie uwagi na czynniki poza-językowe warunkujące potencjalny wpływ języka na myślenie. Przełom ten Dell Hymes nazwał „drugim relatywizmem językowym", relatywizmem funkcji, argumentując, że „konsekwencje relatywizmu struktury językowej zależą od relatywizmu jego funkcji." (Hymes 1996: 44-46). Hymes przyjmuje podejście etnograficzne, które poprzez badanie interakcji w kontekście społecznym umożliwia uchwycenie znaczeń nadawanych im przez użytkowników $\mathrm{w}$ relacji do istotnych $\mathrm{w}$ danej sytuacji aspektów tożsamości, ról społecznych, czy podzielanych doświadczeń w podobnych interakcjach. William Hanks podsumowuje omawiane podejście w następujący sposób:

„Zamiast determinować myśl, formy językowe i zwyczajowe sposoby mówienia umożliwiają, czy też mogą popierać rozwój pewnych sposobów myślenia. (...) Mówiąc prosto, współczesne badania językoznawcze pokazują, że wpływ form językowych na myśl jest 
zasadniczo uzależniony od czynników określanych mianem kontekstu". (Hanks 1996: 234, tłum. MJ)

Hanks podkreśla deiktyczny charakter wszelkich form językowych, ich systemowe niedookreślnie. Oznacza to, że komunikacja może zachodzi tylko i wyłącznie w kontekście społeczno-kulturowym, a to, co przeciętny użytkownik języka traktuje jako podstawowe (czy też słownikowe) znaczenie słowa, wynika według niego z konwencjonalizacji kontekstu danej formy. Skoro zaś znaczenie form językowych jest niedookreślone, nie można już pytać o ich bezpośredni wpływ na myśli (czy o sposób, w jaki mogą je odzwierciedlać). Obrazy mentalne wyprowadzane przez ludzi na podstawie odbieranych wypowiedzi będę zawsze uzależnione od kontekstu kulturalno-społecznego. „Zamiast więc pytać o to, co użytkownicy danego języka moga pomyśleć z powodu kategorii obecnych w ich języku, prawdziwe pytanie brzmi: co zwykle myśla z powodu kształtu ich praktyk.” (Hanks 1966: 266, tłum. MJ, podkr. oryg.).

Przedstawione powyżej ujęcie hipotezy Sapira-Whorfa było wyzwaniem dla współczesnej lingwistyki w takim sensie, że oznaczało konieczność wykroczenia poza dotychczasowe ramy dyscypliny i współpracy z naukami społecznymi. Wyzwanie to było tym trudniejsze, że szło w przeciwnym kierunku do nadanego lingwistyce przez przedstawicieli dominującej w latach sześćdziesiątych i siedemdziesiątych teorii gramatyki generatywnej. Zrobili oni bardzo wiele $\mathrm{w}$ celu ugruntowania lingwistyki jako niezależnej nauki, bliskiej, a w każdym razie zbliżającej się w kierunku nauk ścisłych. Te rozbieżne tendencje sprawily, że w ramach językoznawstwa wykształciły się bardzo liczne subdyscypliny, o których różnorodności świadczyć może fakt, że kierunki lingwistyczne znajdują się dziś zarówno na wydziałach artystyczno-humanistycznych, społecznoekonomicznych jak i ścisłych. Jedną z takich subdyscyplin, znajdującą się na pograniczu jezzykoznawstwa, socjologii i antropologii jest dziedzina obejmująca badania nad ideologiami językowymi. Perspektywa ta rozwinęła się równolegle $\mathrm{z}$ drugą falą zainteresowania relatywizmem i część badaczy, a zwłaszcza jeden $\mathrm{z}$ prekursorów badań ideologii językowych, Michael Silverstein, inspiruje się tematyką poruszaną przez kontynuatorów Sapira i Whorfa. Badania prowadzone w tym nurcie będą nam pomocne $\mathrm{w}$ zrozumieniu relacji pomiędzy naukową feministyczną teorią języka a rozpowszechnionymi wśród sympatyków ruchu feministycznego poglądami na temat języka.

\section{Ideologie językowe}

Ideologie językowe to „zbiory poglądów dotyczących języka formułowane przez użytkowników jako racjonalizacje lub uzasadnienia dla postrzeganej struktury i użycia języka." (Silverstein 1979: 193, tłum. MJ). Należy dodać, że nie każda racjonalizacja postrzeganej struktury języka automatycznie staje się ideologią. Konieczne jest, aby takie poglądy, oceny czy wiedza były podzielane przez wielu członków danej zbiorowości. Odosobnione opinie 
pojedynczych ludzi nie mają bowiem znaczenia z punktu widzenia analizy bytów społecznych.

Silverstein definiuje ideologie językowe jako uświadomione przekonania, o których zwykli użytkownicy są $\mathrm{w}$ stanie mówić, przeciwstawiając się tym samym ujęciom traktującym ideologie jako podświadomą wiedzę, którą możemy poznać jedynie na podstawie zachowania jednostek. Ponadto, zwraca uwagę na jeszcze jedną ważną cechę ideologii językowych, mianowicie na to, że opierają się na postrzeganej strukturze i użyciu języka. Spostrzeżenie to wywodzi się jeszcze $\mathrm{z}$ etnologicznych badań Boasa i Whorfa, którzy zauważyli, że użytkownicy języków indiańskich Ameryki Północnej w sposób zniekształcony opisywali strukturę i użycia języka, jakim się posługiwali (Silverstein 1979: 194). Zdaniem Silversteina, wszelka próba opisu języka przez ludowych lingwistów prowadzić będzie do zniekształcenia przedmiotu dociekań, którą to regułę określa mianem zasady niepewności lingwistycznej (linguistic uncertainty principle). Nie chodzi tu jednak o dyskredytowanie informatorów, jako niewiarygodnych, lecz wskazanie na fakt, że język jest bytem na tyle złożonym, iż możemy jedynie modelować go w sposób niedoskonały. Podkreślić zatem należy, że termin ten nie jest wartościujący, ponieważ kwestia prawdziwości ideologii językowych nie leży w polu zainteresowania badacza.

„Dla nas pojęcie ideologii w jego aktualnym rozumieniu obejmuje przejście określenia konkretnego przedmiotu potencjalnych badań, bez wygłaszania przy tym sądów przynajmniej nie w praktyce naukowej czy akademickiej dotyczących istnienia jakiegoś niezależnego i absolutnego świata Prawdy (przez wielkie P) czy Ważności (pozytywistycznie, nie pozytywnie mówiąc), w których można zmierzyć „błędność” ideologii w stosunku do zakładanych podstawowych „faktów” lub w którym ujawnia się je lub demaskuje na podstawie jakichś polityczno-ekonomicznych korzyści przysparzanych ich posiadaczom". (Silverstein 1998: 124, tłum. MJ)

Zadaniem badacza ideologii językowych nie jest więc ich demaskowanie, lecz badanie pochodzenia i funkcji.

Jedną z najważniejszych cech ideologii językowych jest zdolność do wywoływania zmiany językowej. W najprostszym przypadku proces ten polega na tworzeniu opartego na ideologicznych założeniach modelu języka, który prowadzi do upodobnienia się języka do owego modelu. Obraz oparty na wybranym aspekcie języka zostaje uogólniony na inne aspekty. „Struktura warunkuje ideologię, która następnie wzmacnia i rozszerza oryginalną strukturę, zniekształcając język w imię uczynienia go bardziej podobnym do siebie." (Woolard 1998: 12, tłum. MJ). Przykładem takiego procesu jest standaryzacja języka, która w większości przypadków polega na kodyfikacji wybranych aspektów odmiany języka używanej przez elity danego kraju, a następnie upowszechnienie jej wśród innych grup 
społecznych za pomocą systemu edukacji i mediów. Jednakże często zdarza się, że zmiana językowa przyjmuje kierunek zgoła nieoczekiwany. Dzieje się tak dlatego, że ideologie językowe nie działają w próżni, lecz w społeczeństwie pełnym oddziaływań, które mogą kontestować, wspomagać lub modyfikować rezultaty wpływu ideologii językowych danej grupy. Przykładem takiej sytuacji jest przedstawiony przez Anne Pauwels (1998) proces przekształcenia znaczenia zmian językowych zainicjowanych przez krytykę feministyczną $\mathrm{w}$ języku angielskim. Badaczka analizuje użycia tytułu Ms, który miał zastąpić dwa używane tradycyjnie tytuły Miss i Mrs i - w przeciwieństwie do nich - nie przenosić informacji o stanie matrymonialnym kobiety, wobec której był używany3[3]. Badania Pauwels oraz innych badaczy wskazują jednak, że stosunkowo często tytuł Ms nie jest interpretowany $\mathrm{w}$ zgodzie $\mathrm{z}$ tą intencją (Pauwels 1998: 218). W Kanadzie zdarza się np. traktowanie go jako trzeciego tytułu, używanego przez kobiety rozwiedzione. Badania w Australii wykazały ponadto listę cech, które przypisuje się kobietom używającym tego tytułu. Są wśród nich orientacja ideologiczna (bycie feministką), status zawodowy (praca na stanowiskach zajmowanych przez tzw. białe kołnierzyki) czy orientacja seksualna (bycie lesbijką). Zamiast zredukować asymetrię między męskim tytułem Mr, a dwoma tytułami żeńskimi, nowa forma dodatkowo ją pogłębiła. Jakkolwiek Pauwels (1998: 219) zaznacza, że procent osób poprawnie interpretujących tytuł $M s$ wzrasta, widzimy, że przynajmniej jego początkowa interpretacja była nawet nie tylko różna, ale wręcz sprzeczna z intencjami osób wprowadzających tę formę.

Dysponując powyższą wiedzą możemy wprowadzić rozróżnienie pomiędzy rozpowszechnionymi $\mathrm{w}$ ramach ruchu feministycznego poglądami na temat języka, które nazwiemy ideologiami językowymi, a feministycznymi teoriami językoznawczymi przedstawianymi w publikacjach naukowych. Jakkolwiek wzajemny wpływ jednych na drugie jest jak najbardziej możliwy i prawdopodobny, a sama treść może być w niektórych przypadkach bardzo zbliżona, to jednak dwie kwestie decydują o zasadności wprowadzenia proponowanego podziału. Po pierwsze, ideologie językowe są wiedzą znajdującą się w świadomości społecznej, a co za tym idzie, mającą wpływ na zachowania werbalne jednostek. Możemy się więc spodziewać, że jeśli znacząca grupa użytkowników języka będzie sądzić, że np. wyraz „psycholożka” jest odpowiednim określeniem kobiety wykonującej zawód psychologa, to będzie to miało pewne konsekwencje dla polszczyzny. Pamiętając opisany powyżej przypadek tytułów żeńskich $\mathrm{w}$ języku angielskim, trudno nam jednak z całą pewnością stwierdzić, jakie to będą konsekwencje. Wiedza naukowa z kolei dostępna jest jedynie garstce specjalistów, przez co, o ile nie zostanie spopularyzowana, nie może stanowić podstawy działań społecznych. Po drugie, ideologie

3[3] Rozróżnienie to odpowiada występującym tradycyjnie w języku polskim tytułom „Panna” i „Pani”. Współcześnie jednak podział ten uległ zatarciu i uniwersalnym tytułem stosowany wobec kobiet niezależnie od stanu matrymonialnego jest „Pani”. „Panna jest dziś archaiczną nazwą kobiety niezamężnej (i nierozwiedzionej), używaną systematycznie w kościelnych zapowiedziach przedmałżeńskich, ale bardzo rzadko w dokumentach cywilnych. Panna odpowiada w zapowiedziach przedślubnych nazwie męskiej kawaler, przy czym żadna z tych nazw nie jest używana adresatywnie inaczej niż w żartach.” (Łaziński 2006: 245) 
językowe i wiedza naukowa różnią się z punktu widzenia autora tego artykułu swoją podatnością na krytykę. W przypadku ideologii językowych sympatyków ruchu feministycznego istotne są jedynie odpowiedzi na pytania o genezę, funkcje i potencjalne konsekwencje ich poglądów prawdziwość jest kwestią wtórną, ponieważ ideologie językowe „działają” (tzn. spełniają swoje funkcje i mają realne konsekwencje społeczne) niezależnie od niej. Jednym powodem przeprowadzenia krytyki tych ideologii językowych (rozumianej jako „zdemaskowanie” ich fałszywości) mogłaby być chęć dowartościowania się autora przez wykazanie „,iemnoty mas" - nie taka jest jednak rola nauki. Sytuacja jest dokładnie odwrotna w przypadku wiedzy naukowej - podstawowym wyznacznikiem jej wartości i użyteczności jest adekwatność zawartego $\mathrm{w}$ niej opisu. Poddaje się ją krytyce, mającej na celu wykazanie błędów $\mathrm{w}$ opisie i przedstawienie nowego modelu, mającego lepiej wyjaśniać badane zjawisko. Krytyka jest zatem podstawowym sposobem rozwoju naukowego. Kolejny rozdział będzie próbą przeprowadzenia takiej właśnie krytyki jednego z założeń, które często pojawia się w feministycznych analizach języka.

\section{Relatywizm językowy w lingwistyce feministycznej}

Trzecia fala ruchu feministycznego, dążąca do szeroko zakrojonych zmian w kulturze zdominowanej przez wartości patriarchalne, dostrzegła niezwykle istotną rolę, jaką język pełni $\mathrm{w}$ transmisji tejże kultury. Na skutek tego spostrzeżenia powstało wiele prac naukowych (m.in. Lakoff 1975, Pauwels 1998, Cameron 1990 oraz polskich: Karwatowska i SzpyraKozłowska 2005, Jędrzejko 1994, Błaszkowska i Koniuszaniec 2003), eksplorujących takie tematy jak: różnice i podobieństwa w używaniu języka przez mężczyzn i kobiety, pisarstwo kobiet, założenia teoretyczne badań językoznawczych, czy stereotypy płciowe ukryte $\mathrm{w}$ języku. W artykule tym zajmuję się jedynie ostatnim z wymienionych wątków, ponieważ przebił się on do świadomości społecznej Polaków, wywołując przy tym spore kontrowersje. Jednocześnie zobowiązany jestem podkreślić, że moja analiza ograniczona jest do jednego typu argumentu, który jakkolwiek jest niezwykle rozpowszechniony wśród zwolenników ruchu feministycznego, to jednak stanowi jedynie ułamek kwestii przez nich poruszanych.

Samo sformułowanie przedmiotu badań, którym są „,stereotypy ukryte w języku", oznacza, że celem jaki postawili sobie badacze o orientacji feministycznej jest odnajdywanie i demaskowanie tychże stereotypów. Po dokonaniu takiej demaskacji następnym logicznym krokiem, podejmowanym raczej już przez członków ruchu niż badaczy4[4], jest

\footnotetext{
4[4] Biorąc pod uwagę polityczne zaangażowanie wielu badaczy wywodzących się z tego nurtu, należy zauważyć, że granica między nauką a polityką nie jest zbyt wyraźna. Wiele osób krytycznie nastawionych do ruchu feministycznego traktuje fakt ten jako dowód ideologizacji badań naukowych, który całkowicie je dyskredytuje. Badacze i badaczki gender studies nie uznają tego zarzutu za problematyczny, ponieważ w wielu pracach przeglądowych skutecznie, zdaniem autora tego artykułu, wykazali ideologiczne założenia i polityczne konsekwencje badań wcześniej uznawanych za „obiektywne”. Wychodzą zatem z założenia, że skoro w humanistyce i naukach społecznych nie ma możliwości prowadzenia badań apolitycznych, lepiej jest otwarcie przyznać się do wyznawanych wartości niż ukrywać je za zasłoną źle pojętej „naukowości” i „obiektywizmu”.
} 
dążenie do wprowadzenia zmian w systemie językowym. Zanim jednak do tego dojdzie, musi nastąpić identyfikacja elementu języka, pod którym owe stereotypy się ukrywają. Przedstawię ten proces na podstawie analizy jednego przykładu z książki Małgorzaty Karwatowskiej i Jolanty SzpyryKozłowskiej (2005) Lingwistyka ptci. Ona $i$ on $w$ języku polskim. Czytelnicy albo będą musieli uwierzyć autorowi na słowo, że argumenty o identycznej strukturze powtarzają się zarówno w tej, jak i w innych publikacjach naukowych pisanych w nurcie feministycznej krytyki języka, albo też mogą samemu zapoznać się $\mathrm{z}$ innymi przykładami (np. Karwatowska i Szpyra-Kozłowska 2005: 38, 42, 51; Mills 2008: 31, Błaszkowska i Koniuszaniec 2003).

$\mathrm{W}$ rozdziale poświęconym obrazowi płci w języku autorki analizują kolokacje, idiomy, a także pojedyncze wyrazy, w których mogą ukrywać się odniesienia do tradycyjnych stereotypów płciowych.

(...) rzeczownik 'kawalerka' oznaczający (Słownik języka polskiego 1978: 904) 'niewielkie samodzielne jednopokojowe mieszkanie przeznaczone dla osób samotnych', którego struktura słowotwórcza sugeruje, iż owe osoby są płci męskiej. To z kolei prowadzi do wniosku, iż jedynie samotni mężczyźni, lecz nie kobiety, mają prawo do samodzielnego zamieszkiwania. (Karwatowska i Szpyra-Kozłowska 2005: 47)

W powyższym fragmencie widzimy najbardziej charakterystyczny element tego typu wnioskowania: na podstawie przesłanek odnoszących się jedynie do formalnych właściwości języka, wyprowadza się wnioski dotyczące domniemanych stanów mentalnych, praktyk, czy norm i wartości uznawanych przez jego użytkowników. Połączenie etymologii wyrażeń, ich budowy morfologicznej, czy wreszcie samego istnienia form leksykalnych czy gramatycznych (np. rodzaju męskoosobowego) z szerszymi zjawiskami natury społecznej i psychicznej jest uznawane za w jakimś sensie oczywiste. Jeśli jednak przyjrzymy się uważnie powyższemu fragmentowi, przynajmniej kilka kwestii zmuszeni będziemy uznać za problematyczne.

Po pierwsze, użyty czasownik „sugerować” oznacza, że mamy do czynienia z procesem komunikacyjnym - jakiś nadawca chce przekazać jakiemuś odbiorcy komunikat, który w tym przypadku dotyczy zakwestionowania prawa do samodzielnego zamieszkiwania, a odnosi się w przybliżeniu do połowy populacji. Kim jednak jest nadawca, który chce wyrazić tak dalece seksistowski pogląd? Skoro „kawalerka” jest wyrazem języka polskiego, może wszyscy lub przynajmniej większość Polaków sądzi, że kobiety nie mają prawa mieszkać samotnie? Wydaje się to mało prawdopodobne. Nawet niekoniecznie przyjaznych ruchowi feministycznemu autorów Słownika języka polskiego trudno posądzić o szerzenie tak drastycznych stereotypów, skoro w definicji wyrazu piszą o „osobach samotnych”. W obliczu niemożliwości znalezienia osobowego nadawcy, dochodzi zatem do przypisania intencjonalności systemowi 
językowemu, który „sam” zaczyna wysyłać komunikaty, do swoich użytkowników. Jak piszą Karwatowska i Szpyra-Kozłowska, to struktura słowotwórcza jest nadawcą komunikatu. Posuwając metaforę najdalej, jak tylko się da, można porównać język do komputera HAL z filmu 2001: Odyseja kosmiczna Stnaley’a Kubricka - ludzkiego narzędzia, które zyskuje świadomość i obraca się przeciwko swoim stwórcom.

Zjawisko przypisywania intencji systemowi językowemu w mojej pracy magisterskiej pt. Ideologie językowe. Analiza postaw pracowników Instytutu Filologii Polskiej UAM wobec feministycznej krytyki języka nazwałem alienacja znaczenia, podkreślając tym samym jego podobieństwo do innych sytuacji, w których „(...) wytwory dziatalności ludzkiej (np. idee, produkty pracy, instytucje) autonomizuja się (ulegaja urzeczowieniu i wyobcowaniu) względem swych twórców, $w$ skutek czego traca oni kontrole nad swoimi wytworami, a nawet zostaja przez nie podporzqdkowani regułom dziatania, które odbieraja jako obce lub przeciwstawne w stosunku do swej pierwotnej intencji." (Wojciech Chudy 2000: 189). Pokazałem $\mathrm{w}$ ten sposób, że $\mathrm{w}$ tym konkretnym feministycznym argumencie dotyczącym języka wyraża się ogólnoludzka tendencja do przyznawania faktom społecznym bytu niezależnego od społeczeństwa, w którym powstały.

Czytelnicy przychylni ruchowi feministycznemu mogą uznać, że przedstawiona powyżej analiza jest jedynie nieżyczliwą interpretacją niezbyt precyzyjnie sformułowanego argumentu, a autorki miały jedynie na myśli, że istnienie takich a nie innych struktur $\mathrm{w}$ języku polskim zwiększa naszą skłonność do myślenia w określony sposób. Czytelnicy ci stwierdzą (i będą mieli całkowitą rację), że omawiane autorki z pewnością nie podpisałyby się pod skrajnie alienującą teorią języka przedstawioną powyżej. Spytają też, dlaczego skupiam się na jednym tylko, niewielkim aspekcie feministycznej krytyki języka, całkowicie ignorując jej rozliczne dokonania nie mające żadnego związku z hipotezą Sapira-Whorfa. Uzasadniając wybór tak wąskiego zagadnienia jako tematu tego artykułu, podkreślę dwie kwestie: po pierwsze - powtarzalność tak samo sformułowanego wnioskowania $\mathrm{w}$ wielu publikacjach feministycznych oraz, po drugie (i jak przekonamy się w ostatniej części artykułu, jest to ważniejszy powód) - rozpowszechnienie takiego podejścia wśród nie będących lingwistami zwolenników ruchu feministycznego.

Waga pierwszego $\mathrm{z}$ wymienionych powodów polega na tym, że niezależnie od tego, co autorzy i autorki mają na myśli pisząc, że ten czy inny element struktury językowej „sugeruje” użytkownikom patriarchalne stereotypy, to robiąc tak całkowicie ignorują problematyczność przyjmowanych przez siebie założeń. Stwierdzić, że struktury języka mogą wpływać na procesy myślowe - to jedno. Dużo trudniej już jednak ustalić w jakich warunkach się to dzieje, które aspekty języka i procesów myślowych wchodzą $\mathrm{w}$ te relacje, jaki jest zakres wpływu. Na te pytania próbują współcześnie odpowiedzieć badacze zajmujący się relatywizmem językowym - i trzeba powiedzieć, że znajdywanie nawet wstępnych odpowiedzi przychodzi im z niejakim trudem. Im więcej wiemy na temat 
relacji między językiem i myślą, tym lepiej zdajemy sobie sprawę z wielości społeczno-kulturowych czynników (nazywanych najczęściej kontekstem), które w praktyce uniemożliwiają stwierdzenia prostych przyczynowoskutkowych relacji między poszczególnymi formami językowymi a ideami. Tymczasem krytyka feministyczna zdaje się całkowicie nie dostrzegać złożoności założenia, które przyjmuje za intuicyjnie oczywiste.

Podsumowując powyższy rozdział chciałbym pokreślić, że moja krytyka jednego z najczęściej pojawiających się argumentów w dyskursie feministycznym na temat języka nie kwestionuje dotyczących rzeczywistości społecznej wniosków, kwestionuje sposób w jaki się do nich dochodzi. W innym miejscu Karwatowska i Szpyra-Kozłowska (2005: 42) stwierdzają, iż brak żeńskiego odpowiednika idiomu prawdziwa męska przyjaźń może sugerować, że kobiety nie potrafią się prawdziwie przyjaźnić. Jest to może dość daleko posunięty wniosek, ale z pewnością zgodzilibyśmy się z faktem, że istnieją w społeczeństwie polskim stereotypy przedstawiające kobiety jako kłótliwe i plotkarskie. Kluczowe jest jednak to, że istnienie idiomu, czy też (jak w tym przypadku) jego brak, nie jest przesłanką pozwalającą na wyciągnięcie takiego wniosku. Możemy wymyślić nieskończenie wiele idiomów, których nie ma w języku polskim i argumentować, że mówi nam to coś na temat mentalności Polaków, jednakże nie będzie to metoda naukowa, a jedynie spekulacja. Chęć wyciągania takich wniosków jest niebezpieczną drogą na skróty (charakterystyczną też dla wczesnych entuzjastów hipotezy SapiraWhorfa), zwłaszcza w obliczu nauk społecznych, które wypracowały pełen wachlarz metod pozwalających badać opinie grup społecznych w sposób naukowy.

To powiedziawszy chciałbym zakończyć część pracy, w której poddałem krytyce pewien sposób myślenia o języku obecny $\mathrm{w}$ feministycznych teoriach naukowych i przejść do analizy tego samego sposobu myślenia obecnego w świadomości społecznej części użytkowników języka, czyli innymi słowy spojrzeć na niego z punktu widzenia teorii ideologii językowych.

\section{Brakujący element układanki - współczynnik humanistyczny}

Gdyby przeanalizowane w poprzednim rozdziale podejście występowało jedynie w pracach naukowych językoznawców i badaczy gender studies, niniejszy artykuł mógłby zakończyć się w tym miejscu. Tak się jednak składa, że akademicka krytyka feministyczna idzie w parze $\mathrm{z}$ szerszym ruchem społecznym, który za cel stawia sobie wprowadzenie zmiany kulturowej. Trudno dokładnie oszacować rozmiary tej zbiorowości, zwłaszcza biorąc pod uwagę wpływ negatywnych skojarzeń (jakie w dyskursie publicznym związane są z feminizmem) na skłonność ludzi do deklarowania przynależności do tego ruchu. Tym bardziej zaś trudno 
ocenić wpływ jaki feminizm jest w stanie wywierać na język5[5]. Nie zmienia to jednak faktu, że istnieje $\mathrm{w}$ Polsce grupa ludzi podzielających wartości ruchu feministycznego, dążących do wprowadzenia zmian językowych zgodnych ze swoimi poglądami. Jak dostrzec można na forach internetowych, w artykułach publicystycznych czy wypowiedziach polskich feministek, opisany $\mathrm{w}$ poprzednim rozdziale pogląd uznający strukturę języka za narzędzie podtrzymujące patriarchalną ideologię jest szeroko rozpowszechniony ${ }^{6[6]}$.

Spostrzeżenie to zmusza nas do przyjęcia innej perspektywy. Nie mówimy już o teorii naukowej, która lepiej lub gorzej opisuje rzeczywistość społeczną, lecz o poglądach grupy ludzi, które w przyjętej przeze mnie perspektywie określa się mianem ideologii językowej. W mniejszym stopniu interesuje nas teraz „zgodność myśli z rzeczywistościa”, w większym zaś przyczyny powstania i popularyzacji określonych myśli, ich funkcje społeczne oraz skutki, jakie wynikają z ich istnienia w świadomości społecznej grupy.

Jedną z uderzających cech feministycznych interpretacji struktury językowej jest to, jak łatwo są one akceptowane przez uczestników ruchu i jak bardzo oczywiste im się wydają, kiedy już dowiedzą się o ich istnieniu. Nie każdy zdaje sobie na przykład sprawę $\mathrm{z}$ istnienia $\mathrm{w}$ języku polskim form męskoosobowych i niemęskoosobowych. Jednakże w chwili, w której osoba o poglądach feministycznych dowie się o istnieniu takiego podziału, to jedyną możliwą dla niej do pomyślenia interpretacją będzie uznanie „faktu” wyróżnienia mężczyzn osobną formą, podczas gdy kobiety dzielą swoją ze zwierzętami i przedmiotami nieożywionymi, uznając to za niesprawiedliwość społeczną i przejaw dyskryminacji. Co ciekawe, wielu osobom $^{7[7]}, \mathrm{w}$ tym także niektórym lingwistom ${ }^{8[8]}$, taka interpretacja wydaje się bezsensowna lub $\mathrm{w}$ najlepszym razie naciągana. To samo można powiedzieć o analizowanym wcześniej fragmencie dotyczącym wyrazu „kawalerka” - dla jednych będzie on świadectwem dyskryminacji kobiet $\mathrm{w}$ języku, dla innych zaś nie. Fascynujące jest jednak, skąd biorą się takie interpretacje i co czyni je na tyle silnymi, że ich zwolennicy (i przeciwnicy)

5[5] Zdarza się bowiem, że zmiany oceniane pozytywnie przez ruch feministyczny zachodzą bez jego świadomej ingerencji. Najlepszym przykładem jest tutaj wspomniane wcześniej zniknięcie z języka polskiego rozróżnienia w tytułach kobiet na Paniq̨ i Pannę. Panna wyszła z użycia zanim ruch feministyczny w Polsce zdążył rozwinąć się na tyle, żeby propozycja jej usunięcia przebiła się do świadomości społecznej.

6[6] Niniejsza publikacja nie jest w stanie pomieścić przeglądu tego typu poglądów. W tym miejscu mogę jedynie przywołać kilka przykładów z prac uczniów liceów z regionalnego etapu Olimpiady Literatury i Języka Polskiego z 2008, w którym jednym z dostępnych tematów był „Język a płeć”: „Większość ofert pracy wygląda tak, jakby była skierowana wyłącznie do mężczyzn.”, „(..) język polski, jak również i inne języki świata, wykazują skłonność do złego traktowania kobiet.”, „Forma specjalista użyta w tytule [ogłoszenia o pracę] sugeruje, że tylko mężczyźni mogą ubiegać się o to stanowisko."

7[7] Nie szukając daleko, 4826 członkom grupy „Feminizacja języka polskiego boli mnie w uszy” na portalu społecznościowym Facebook. 8[8] Pewien wykładowca specjalizujący się w gramatyce języka polskiego, z którym miałem okazję przeprowadzić wywiad w ramach badań do pracy magisterskiej, utrzymywał np. że interpretacja feministyczna jest błędna, ponieważ wynika z nieznajomości procesów historycznego rozwoju polszczyzny, które doprowadziły do wykształcenia form męsko- i niemęskoosobowych. Podział na te formy nie wynika według niego z potrzeby „wyróżnienia mężczyzn”, a z ekspansji form żeńskich, których zakres użycia rozszerzył się na formy nijakie. Obecność alternatywnych wyjaśnień tych samych faktów jest świadectwem istnienia konkurencyjnych ideologii językowych, których zwolennicy dążą do przypisania swojej wersji statusu bezdyskusyjnej wiedzy zdroworozsądkowej (przez Silversteina i Urbana (1996: 11-12) określany stanem autorytatywnej metadyskursywnej entekstualizacji). 
organizują się w grupy mające na celu zmienić język tak, aby wyeliminować przynajmniej część form uznawanych za dyskryminujące (lub zapobiec tej zmianie)?

Odpowiedzi na to pytanie dostarczyć może jedno z pojęć wprowadzonych do badań ideologii językowych przez Judith Irvine i Susan Gal (2000). Na podstawie przeglądu literatury oraz badań własnych nad językami Południowej Afryki i Europy Południowo-Wschodniej, autorki stwierdziły regularne występowanie podobieństw $\mathrm{w}$ tym, jak ludzie $\mathrm{z}$ różnych języków i kultur „(...) lokalizują, interpretuja $i$ racjonalizuja złożoność socjolingwistyczna języków (...)" (Irvine i Hal 2000: 36). Zidentyfikowały trzy procesy semiotyczne charakterystyczne dla popularnych racjonalizacji struktury językowej: ikonizację (iconization), usunięcie (erasure) i fraktalną rekursywność (fractal recursivity). Ikonizacja polega na wykształceniu semiotycznej relacji między elementami zróżnicowania językowego a obrazem grupy społecznej, której przypisuje się używanie owych wariantów. Na skutek tego procesu elementy struktury językowej stają się ikonicznymi reprezentacjami grupy ludzi, będąc w jakimś sensie obrazem przypisywanych jej cech. Przykładem może być uznawanie wariantów fonetycznych odbiegających od standardowej odmiany języka („połykanie liter”) za świadectwo niedbałości i lenistwa określonej grupy użytkowników lub - występujące w kulturach anglojęzycznych - traktowanie obecnego w niektórych dialektach podwójnego przeczenia jako dowodu potwierdzającego ograniczoną zdolność do logicznego myślenia użytkowników tych dialektów. Istotą drugiego $\mathrm{z}$ wprowadzonych przez Irvine i Hal pojęć, usunięcia, jest uproszczenie zróżnicowania językowego, którego rezultatem jest uczynienie określonej grupy lub praktyki społecznej niewidoczną. Fakty nie pasujące do stereotypu zostają albo zignorowane, albo wyjaśnione np. jako wyjątki.

Zarówno ikonizacja jaki i usunięcie są pojęciami, które mogłyby wzbogacić analizę debaty dotyczącej feministycznej reformy języka. Jednakże to fraktalna rekursywność oferuje interesujące wyjaśnienie fenomenu popularności omawianej w tej pracy feministycznej interpretacji „seksistowskich” form języka polskiego. Autorki określają ją jako „(...) projekcje opozycji istotnej na określonym poziomie relacji na inny poziom" (Irvine i Gal 2000: 38, tłum. MJ). Jako przykład podają opisywanie relacji poza-grupowych tak, jakby odpowiadały relacjom wewnątrz grupy. Odwołanie do fraktali jest metaforą służącą lepszemu zobrazowaniu tego procesu. Rzeczone fraktale są figurami geometrycznymi, których cechą charakterystyczną jest to, że wyglądają tak samo, niezależnie od tego z jakiej odległości się na nie patrzy - powielają tę samą strukturę na dowolnym poziomie zbliżenia. Podobnie rzecz ma się $\mathrm{z}$ ideologiami, których siła polega na zdolności wyjaśnienia niemalże dowolnego elementu rzeczywistości społecznej. Efektem wprowadzenia tego pojęcia jest zwrócenie uwagi na podatność tej niesłychanie złożonej struktury, jaką jest język, na „odnajdywanie” w niej „faktów” potwierdzających wyjściowe założenia. 
W interesującym nas przypadku chodziłoby zatem o projekcję narracji dotyczącej dyskryminacji kobiet na poziom struktur języka. Interpretacja taka jest skuteczna przede wszystkim z dwóch względów: patriarchalnego charakteru społeczeństwa, w którym została ukształtowana współczesna polszczyzna oraz istnienia dobrze ugruntowanej feministycznej tradycji demaskowania ukrytych form dyskryminacji. Trudno zaprzeczyć, że istnieje związek między tym, że małe mieszkania nazywamy kawalerkami, a tym, że historycznie były one często zamieszkiwane przez kawalerów. Pytanie (do którego za moment powrócę) brzmi, jakie ma to znaczenie dzisiaj? Krytyka feministyczna wykazała zaś istnienie wielu form dyskryminacji działających skutecznie bez świadomości i przy „dobrej wierze" osób uczestniczących w podtrzymywaniu wartości patriarchalnych. Jest więc niezwykle wyczulona na pozornie niewinne praktyki, które po dokładniejszej analizie okazują się być częścią mechanizmów dyskryminacji. Wziąwszy to pod uwagę zaskakujące byłoby, gdyby ukształtowana $\mathrm{w}$ realiach patriarchalnych i podejrzewana o zdolność kształtowania myśli struktura języka nie znalazła się w centrum uwagi feministek.

Jakie ma jednak znaczenie, że pewna grupa ludzi zakłada prawdziwość hipotezy, którą z naukowego punktu widzenia należałoby uznać za problematyczną? Sytuacja taka nie jest bynajmniej wyjątkowa, dlaczego więc badacz dążący do zrozumienia wpływu, jaki język może wywierać na myślenie, miałby się przejmować tym, co myślą na ten temat pozostali użytkownicy języka. Otóż główna teza, którą chciałbym postawić na zakończenie tego artykuł, głosi, że bez poznania ideologii językowych i sprzężonych z nimi wartości społecznych nie jesteśmy w stanie stwierdzić czy język ma jakikolwiek wpływ na funkcjonowanie patriarchalnych (bądź jakichkolwiek innych) aspektów naszej kultury. Błąd wczesnych interpretatorów Sapira i Whorfa, który obecnie powieliła akademicka feministyczna krytyka języka, polegał na założeniu, że możliwe jest oddzielenie (obiektywnej) struktury języka od kultury posługującego się nią społeczeństwa i badanie wpływu jednego zjawiska na drugie. Metodologiczny zabieg wyodrębnienia formalnych właściwości języka, skuteczny $\mathrm{w}$ wielu subdyscyplinach lingwistyki, w tym przypadku efektywnie uniemożliwia zrozumienie procesu, który chcemy zbadać. Dzieje się tak dlatego, że - jak tłumaczą omówieni powyżej współcześni badacze relatywizmu językowego - znaczenie form, a także ich potencjalny wpływ na procesy myślowe użytkowników uzależniony jest od kontekstu, którego częścią są ideologie językowe.

Jeśli istnieją ludzie uważający, że jest coś niewłaściwego w praktyce samotnego zamieszkiwania kobiet i powiążą swoje przekonania $\mathrm{z}$ etymologią wyrazu „kawalerka”, wtedy możemy podejrzewać, że użycie tego wyrazu w pewnych kontekstach poza denotacją małego mieszkania będzie konotować wartości ograniczające wolność kobiet. W odwrotnej sytuacji, kiedy np. nikt nie sądzi, że Słońce obraca się wokół Ziemi mimo, że wyrażenie „słońce wschodzi” mogłoby to właśnie „sugerować”, nawet setki lat używania tego zwrotu nie sprawiły, że powróciliśmy do przekonań 
sprzed przewrotu Kopernikańskiego9[9]. Jeśli wrócimy teraz do przykładu, od którego rozpocząłem ten artykul, dotyczącego domniemanych różnic $\mathrm{w}$ obrazach mentalnych systemów drogowych pomiędzy osobami hispanojęzycznymi a użytkownikami języka portugalskiego, to stwierdzimy, że na podstawie samej różnicy w etymologiach wyrazów określających zjazd z autostrady nie jesteśmy w stanie wyciągnąć żadnych wniosków. Można sobie jednak wyobrazić sytuację, np. odbywające się w parlamencie głosowanie nad rozbudową systemu drogowego, które jest poprzedzone burzliwą społeczną debatą nad kształtem proponowanego planu, w wyniku której użytkownicy języka nadadzą temu wyrazowi konotację ideologiczną. Forma wyrazu nie determinuje tej interpretacji jedynie ją umożliwia. Patrząc z perspektywy feministek, wydaje się prawdopodobne, że ponieważ polszczyzna (podobnie jak inne języki) została ukształtowana $\mathrm{w}$ społeczeństwie patriarchalnym, to jej struktury dużo łatwiej dają się interpretować jako wyrażające wartości patriarchalne (do tego ostatecznie ich używano). Jednakże społeczna realność takich interpretacji zależy od tego, czy istnieją odpowiednio liczne grupy ludzi, którzy je podzielają. Dopiero uwzględnienie społecznego wymiaru tych interpretacji pozwala ocenić ich znaczenie.

Nauki społeczne wykształciły całą grupę pojęć i teorii kładących nacisk na realne znaczenie nawet całkowicie niezgodnych $\mathrm{z}$ „prawdą” poglądów, jeśli tylko wejdą one do świadomości społecznej grupy. Począwszy od teorematu Thomasa, który mówi, że ,jeśli ludzie określają sytuacje jako realne, to maja one realne konsekwencje" (Merton 1995: 380, tłum. MJ), poprzez omawiane np. przez Anthony'ego Giddensa (2007: 731) koncepcje związane z samo-spełniającymi się przepowiedniami, po współczynnik humanistyczny Floriana Znanieckiego, w którym polski socjolog kładł nacisk na badanie znaczeń, jakie ludzie sami nadają sytuacjom, przedmiotom i praktykom. Badacze ci od początku zdawali sobie sprawę, że rzeczywistość społeczna różni się zasadniczo od przedmiotu badań nauk przyrodniczych, a najważniejsza $\mathrm{z}$ różnic polega na istnieniu świata intersubiektywnych znaczeń, który nadaje sens praktykom społecznym. Dopiero uwzględnienie w teoriach i metodach badawczych językoznawstwa współczynnika humanistycznego przybliży nas do zrozumienia relacji między znakiem a myślą.

\section{Zakończenie}

Podsumowując, chciałbym jeszcze raz podkreślić: z powyższej analizy nie wynika, że krytyka feministyczna myli się utrzymując, iż struktury języka wpływają na podtrzymywanie wartości patriarchalnych. Utrzymuję jedynie, że stwierdza taką zależność pochopnie, na podstawie

\footnotetext{
9[9] I przywoływana często możliwość użycia języka w funkcji poetyckiej nadal nie przekonuje nas do przyjęcia teorii heliocentrycznej. Możemy wyobrazić sobie „słońce wędrujące po widnokręgu”, a jeśli każemy ludziom nadać imiona przedmiotom martwym, w statystycznie istotnej ilości przypadków płeć nadana przedmiotom będzie wynikać z rodzaju gramatycznego wyrazów je określających. Fakt, że język daje nam takie możliwości nie oznacza, że muszą one być wykorzystane. Powtórzę więc jeszcze raz za Hanksem, że „[z]amiast (...) pytać o to, co użytkownicy danego języka moga pomyśleć z powodu kategorii obecnych w ich języku, prawdziwe pytanie brzmi: co zwykle myślą z powodu kształtu ich praktyk." (Hanks 1966: 266, tłum. MJ, podkr. oryg.).
} 
niekompletnych danych. Nie zmienia to faktu, że intuicyjnie wyciągnięty wniosek może być czasem trafny. Jednakże obecny stan rzeczy nie sprzyja ani naukowemu zrozumieniu niezwykle złożonego problemu, z którym mamy do czynienia, ani nie ułatwia publicznej debaty na ten temat. Zwłaszcza, gdy jedna ze stron powołuje się na własne, indywidualne odczucia, których druga strona może nie podzielać. Dopiero badania społecznego rozkładu ideologii i praktyk językowych dotyczących spornych form dostarczyłyby rzeczowych argumentów, pozwalających ocenić postulaty feministek. Z kolei wyznaczone na takiej podstawie postulaty reformy języka zyskałyby większą wiarygodność, co niewątpliwie ułatwiłoby ich wdrożenie. Niezależnie jednak, czy takie badania powstaną i czy zostaną dostrzeżone przez aktywistów językowych po którejkolwiek stronie barykady, zarówno ideologie językowe jak i struktura języka nie przestaną się zmieniać i wzajemnie na siebie wpływać, dostarczając nam tematów do dyskusji, ale i jakże cennych argumentów przeciwko tym, z którymi się nie zgadzamy. Jak wiemy bowiem - język nie tylko umożliwia komunikację, służy także do dzielenia ludzi. 


\section{Bibliografia}

Aneta Pavlenko (2005). Bilingualism and Thought. [W:] J. Kroll, A. de Groot (red.) Handbook of Bilingualism. Psycholinguistic Approaches, 433-453.

Błaszkowska, Hanka i Gabriela Koniuszaniec (2003). Language and gender in Polish. [W:] Marlis Hellinger i Hadumod Bußmann (red.) Gender Across Languages. The linguistic representation of men and women. Volume 3. John Benjamins Publishing Company.

Cameron, Deborah (1990). Introduction: why is language a feminist issue? [W:] D. Cameron (red.) The Feminist Critique of Language. A reader. New York: Routledge, 1-28.

Chudy, Wojciech (2000). Alienacja. [W:] Powszechna Encyklopedia Filozofii. Polskie Towarzystwo Tomasza z Akwinu.

Clark, Herbert (1996). Communities, Commonalities, and Communication. [W:] J. Gumperz i Stephen Levinson (red.) Rethinking Linguistic Relativity. Cambridge: Cambridge University Press, 324-355.

Giddens, Anthonty (2007) [2001]. Socjologia. tłum. A. Szulżycka, Warszawa: Wydawnictwo Naukowe PWN.

Hanks, William F. (1996). Language form and communicative practices. [W:] J. Gumperz, S. Levinson (red.) Rethinking Linguistic Relativity. Cambridge: Cambridge University Press, 232-270.

Hymes, Dell (1996). Ethnography, Linguistics, Narrative Inequality: Toward an Understanding of Voice. Routledge.

Irvine and Gal (2000) Language Ideology and Linguistic Differentiation . [W:] P. Kroskrity (red.) Regimes of language: Ideologies, Polities, and Identities. Santa Fe: School of American Research Press, 35-84.

Jędrzejko, Ewa (1994). Kobieta w przysłowiach, aforyzmach i anegdotach polskich. Konotacje i stereotypy. [W:] J. Anusiewicz i K. Handke (red.) Język a kultura T. 9 Pteć $w$ języku i kulturze. 9-29, 159-172.

Karwatowska, Małgorzata i Jolanta Szpyra-Kozłowska (2005). Lingwistyka płci. Ona $i$ on $w$ języku polskim. Wydawnictwo Uniwersytetu Marii CurieSkłodowskiej.

Kay, Paul (1996). Intra-speaker Relativity. [W:] J. Gumperz i S. Levinson (red.) Rethinking linguistic relativity. Cambridge: Cambridge University Press, 97114.

Lakoff, George (1987). Women, fire, and dangerous things. What categories reveal about the mind. University of Chicago Press.

Lakoff, Robin (1996). Language and woman's place. New York: Harper.

Łaziński, Marek (2006). O panach i paniach. Polskie rzeczowniki tytularne i ich asymetria rodzajowo-ptciowa. Warszawa: Wydawnictwo Naukowe PWN.

Levinson, Stephen (2003). Space in language and cognition. Cambridge: Cambridge University Press.

Lucy, John (1992). Grammatical categories and cognition. A case study of linguistic relativity hypothesis. Cambridge: Cambridge University Press.

Lucy, John (1996). The scope of linguistic relativity: An analysis and review of empirical research. [W:] J. Gumperz i S. Levinson (red.), Rethinking linguistic relativity. Cambridge: Cambridge University Press, 37-69.

Merton, Robert (1995). Thomas Theorem and The Matthew Effect. Social Forces, 74(2): 379-424.

Pauwels, Anne (1998). Women changing language. London, New York: Longman. 
Michal Jahns: Gdy mówi do nas język. Krytyczne spojrzenie...

Sapir, Edward (1921). Language. An introduction to the study of speech. New York: Harcout, Brace \& Company.

Sapir, Edward (1929). The status of linguistics as a science. Language 5, 201-14.

Silverstein, Michael (1979). Language Sturcture and Linguistic Ideology, [W:] P. Clyne, W. Hanks, i C. Hofbauer (red.) The Elements: A parasession on linguistic units and levels, Chicago Linguistic Society, University of Chicago, $193-247$.

Silverstein, Michael (1998). The Uses and Utility of Ideology. [W:] B. Schieffelin, K. Woolard, P. Kroskrity (red.) Language Ideologies. Practice and Theory. Oxford University Press, 123-148.

Silverstein, Michael i Greg Ubran (1996). Natural histories of discourse. Chicago: University of Chicago Press.

Slobin, Dan (1996). From "thought and language" to "thinking for speaking". [W:] J. Gumperz i S. Levinson (red.) Rethinking linguistic relativity. Cambridge: Cambridge University Press, 70-96.

Whorf, Benjamin (1956). Language, thought and reality. New York: Wiley.

Woolard, Kathryn A. (1998). Introduction: Language Ideology as a Field of Inquiry, [W:] B. Schieffelin, K. Woolard, P. Kroskrity (red.) Language Ideologies. Practice and Theory, Oxford University Press, 3-50.

Znaniecki, Florian (1936). Social actions. New York: Farrar \& Rinehart. 